\title{
Description of the female, pupa and gall of Pisphondylia brasiliensis Couri and Maia, 1992 (Diptera: Cecidomyiidae, Schizomyiina) with new records
}

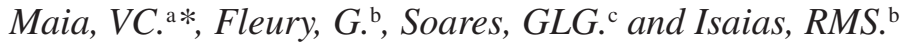 \\ aDepartamento de Entomologia, Museu Nacional, Quinta da Boa Vista, São Cristóvão, \\ CEP 20940-040, Rio de Janeiro, RJ, Brazil \\ 'Laboratório de Anatomia Vegetal, Instituto de Ciências Biológicas, \\ Universidade Federal de Minas Gerais - UFMG, Av. Antônio Carlos, 6627, Pampulha, Belo Horizonte, MG, Brazil \\ 'Departamento de Botânica, Instituto de Biologia, \\ Universidade Federal do Rio Grande do Sul - UFRS, Av. Paulo Gama, s/nº, Porto Alegre, RS, Brazil \\ *e-mail: maiavcid@acd.ufrj.br \\ Received April 1, 2009 - Accepted August 5, 2009 - Distributed November 30, 2010
}

(With 12 figures)

\begin{abstract}
The gall of Pisphondylia brasiliensis on Guapira opposita, its female and pupa are described and illustrated. The geographic distribution of this species is now widened to Minas Gerais and Rio Grande do Sul (Brazil). For the first time, a female of the genus is described.
\end{abstract}

Keywords: Asphondyliini, Cecidomyiidae, Diptera, Pisphondylia brasiliensis, Schizomyiina.

\section{Descrição da fêmea, pupa e galha de Pisphondylia brasiliensis Couri and Maia, 1992 (Diptera: Cecidomyiidae, Schizomyiina) com novos registros}

\section{Resumo}

A galha de Pisphondylia brasiliensis em Guapira opposita, a fêmea e a pupa são descritas e ilustradas. A distribuição geográfica dessa espécie é ampliada para Minas Gerais e Rio Grande do Sul (Brasil). Pela primeira vez, uma fêmea do gênero é descrita.

Palavras-chave: Asphondyliini, Cecidomyiidae, Diptera, Pisphondylia brasiliensis, Schizomyiina.

\section{Introduction}

Guapira opposita Vell (Reitz) (Nyctaginaceae) is an arboreous-arbustive species of wide distribution, occurring all over Brazil, in diverse habitats from rain forests to rupestrian fields. The species exhibits large phenotypic plasticity in response to environmental variation (Furlan, 1996). This species is a superhost for galling insects within which Pisphondylia brasiliensis Couri and Maia, 1992 can be found (Maia, 2005).

Pisphondylia Möhn, 1960 is known from two Neotropical species that induce galls on Nyctaginaceae: P. salvadorensis Möhn, 1960 described from El Salvador (larva, pupa, male, and gall) (Möhn, 1960) and P. brasiliensis described from Rio de Janeiro state, Brazil (male and gall). The genus can be recognised by the following characteristics: male antennal circumfila longitudinally sinuous; three-segmented palpus; simple tarsal claws; rudimentary empodia; teeth of gonostyli denticulate; parameres absent; aedeagus bulbous; pupal antennal horns absent and dorsal abdominal spines present; larval spatula absent and anal segment elongated. The female is currently unknown.

In this paper, the female, and pupa of $P$. brasiliensis are described, and gall morphology is revised and illustrated. The former is compared with females of other Schizomyiina genera in order to complete the genus definition. The pupa is compared with that of $P$. salvadorensis. Furthermore, the geographic distribution of $P$. brasiliensis is widened to include records in Minas Gerais and Rio Grande do Sul (Brazil).

\section{Material and Methods}

Galls of $P$. brasiliensis were collected in November, 2007 in a rupestrian field of ferruginous "canga" at Brumadinho, Minas Gerais, Brazil, and in February of 2008 in a semi deciduous seasonal forest in Porto Alegre, Rio Grande de Sul, Brazil. To obtain adults and pupal exuviae, part of the samples was brought back to the laboratory and kept in 
plastic pots layered at the bottom with damp cotton and covered by a fine mesh. These pots were checked daily. To obtain pupae and perform gall microscopical analysis, part of the samples was dissected under a stereoscopic microscope.

Insect specimens were first preserved in $70 \%$ ethanol and later mounted on microscope slides following the methodology of Gagné (1994). Galls were fixed in formalinacetic acid-50\% ethanol (FAA) (1:1:18) (Johansen, 1940) for 48 hours, washed in 50\% ethanol and transferred to $70 \%$ ethanol. Part of the samples were dehydrated in n-buthyl series (Johansen, 1940) and embedded in Paraplast (Kraus and Arduin, 1997). Transverse sections (12 $\mu \mathrm{m})$ were obtained with a rotatory microtome (Biocut Jung), and stained in $0.5 \%$ astrablue-safranin (2:8) (v/v). Schematic drawings were made using an Olympus BH2-DA drawing attachment connected to an Olympus light microscope (Olympus BH2/BHS).

All insect material was deposited in the Diptera collection of Museu Nacional, Rio de Janeiro (MNRJ), and plant material at the BHCB Herbarium.

\section{Results}

\subsection{Female description}

Adult. Body length (from vertex to bilobed structure at posterior end of tergite 8): 3.55-4.30 mm $(\mathrm{n}=5)$. Head: eye facets hexagonal, closely appressed. Antenna: scape obconic, 0.10-0.12 mm long, 0.07-0.09 mm wide, 1.1-1.6 as long as wide; pedicel short, globose, 0.05-0.06 mm long $(n=6)$; flagellomeres $9-12$ progressively and conspicuously shortened (Figure 1); flagellomere neck short and bare. Flagellomeres 1 and 2 not connate, flagellomere 1: 0.25-0.28 $\mathrm{mm}$ long, and 1.0-1.13 times longer than flagellomere 2; flagellomere 2: 0.23-0.25 mm long, and 1.04-1.13 times longer than flagellomere 3; flagellomere 3: $0.21-0.23 \mathrm{~mm}$ long, and 1.04-1.15 times longer than flagellomere 4; flagellomere 4: 0.20-0.21 mm long, and 1.0-1.05 times longer than flagellomere 5; flagellomere 5: 0.19-0.21 $\mathrm{mm}$ long, and 1.0-1.05 times longer than flagellomere 6; flagellomere 6: 0.19-0.20 mm long, and 1.0-1.17 times longer than flagellomere 7; flagellomere 7: 0.17-0.19 mm long, and 1.0-1.35 times longer than falgellomere 8; flagellomere 8: 0.14-0.17 mm long, and 1.16-1.33 times longer than flagellomere 9; flagellomere 9: 0.12-0.13 mm long, and 1.18-1.33 times longer than flagellomete 10; flagellomere 10: 0.09-0.13 mm long, and 1.42-1.83 times longer than flagellomere 11; flagellomere 11: 0.06-0.07 mm long, and 1.2-1.4 times longer than flagellomere 12; and flagellomere 12: 0.06-0.05 mm long $(n=6)$. Circumfila wavy (Figure 2). Frontoclypeus with 22-36 setae $(n=2)$. Labrum long-attenuate. Hypopharynx of the same shape of labrum, with long anteriorly directed lateral setulae. Labella elongate-convex, each with some lateral setae and three pairs of short mesal setae. Palpus with three setose segments: segment one globoid, 0.03-0.04 mm long, and 0.03-0.04 mm wide; segment 2 ovoid, 0.05-0.06 mm long,
0.035-0.04 mm wide, 1.25-1.71 times as long as wide, and 1.25-1.66 times longer than segment 1 ; segment 3 cylindrical, tapering to apex, 0.11-0.12 mm long, 0.03-0.035 mm wide, 3.6-4.0 times as long as wide, and 1.8-2.4 times longer than segment 2.

Thorax. Anepimeron setose, other pleural sclerites asetose. Wing length (from arculus to apex): 3.20-3.30 mm $(\mathrm{n}=5)$. Simple tarsal claws, curved beyond midlength, similar on all legs; empodia rudimentary (Figure 3).

Abdomen (Figure 4): tergites 1-7 rectangular, with complete row of posterior setae, several lateral setae, some setae at midlength, two basal trichoid sensilla and elsewhere with scattered scales. Tergite 8 laterally notched, with complete row of posterior setae. Sternites 2-6, with setae more abundant at midlength, complete row of posterior setae, several lateral setae, two basal trichoid sensilla and elsewhere with scattered scales. Sternite 7 with many scattered setae at distal 4/5 distal (bare at basal 1/5) and 1.7-2.0 times as long as sternite 6. Sternite 8 not sclerotised. Ovipositor protrusible, elongated, pliable, with long ventral, sparse dorsal setae and tiny cercus (Figure 5);
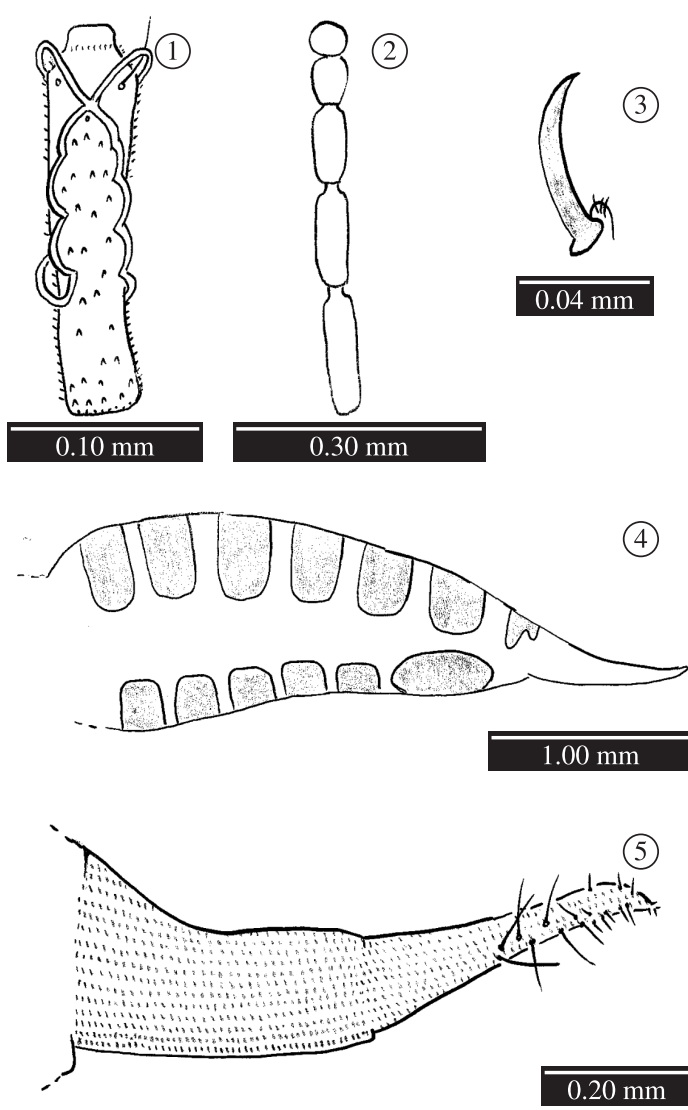

Figure 1-5. Female of Pisphondylia brasiliensis. 1) flagellomere 4, circumfila; 2) flagellomeres 9-12;3) midleg, tarsal claw and empodium; 4) abdominal segment 2 to end, lateral view; and 5) ovipositor, lateral view. 
when completely protracted $0.75 \mathrm{~mm}$ long (from caudal margin of tergite 8 to apex).

Material examined. Porto Alegre, Rio Grande do Sul, Brazil, 20.II.2008, Geraldo Soares and Graziela Fleury col.: 6 females (emergence on 03.II.2008).

\subsection{Pupa description}

Colour: brownish. Length: 3.2-4.4 mm $(\mathrm{n}=4)$. Head (Figure 6): antennal horn triangular $0.02 \mathrm{~mm}$ long $(\mathrm{n}=4)$, apicomesal margin not serrated; cephalic setae 0.07-0.09 mm long ( $\mathrm{n}=4$ ) (Figure 7); two upper frontal horns triangular, $0.03 \mathrm{~mm}$ long $(n=4)$; two lower frontal horns triangular, $0.01 \mathrm{~mm}$ long $(\mathrm{n}=4)$; two pairs of lower facial papillae: one pair setose, seta $0.03 \mathrm{~mm}$ long $(n=4)$, the other asetose; two pairs of lateral facial papillae: one pair setose, seta rudimentary $(<0.01 \mathrm{~mm}$ long) $(n=4)$, the other without setae. Upper cephalic margin laterally thickened.

Thorax: thoracic segments with three pairs of dorsal papillae: two pairs setose and the other asetose, and two pairs of pleural papillae setose (Figure 8); prothoracic spiracle rudimentary (Figure 9).

Abdomen (Figure 10): segments 2-9 with two irregular transverse rows of dorsal spines, distal spines longer than
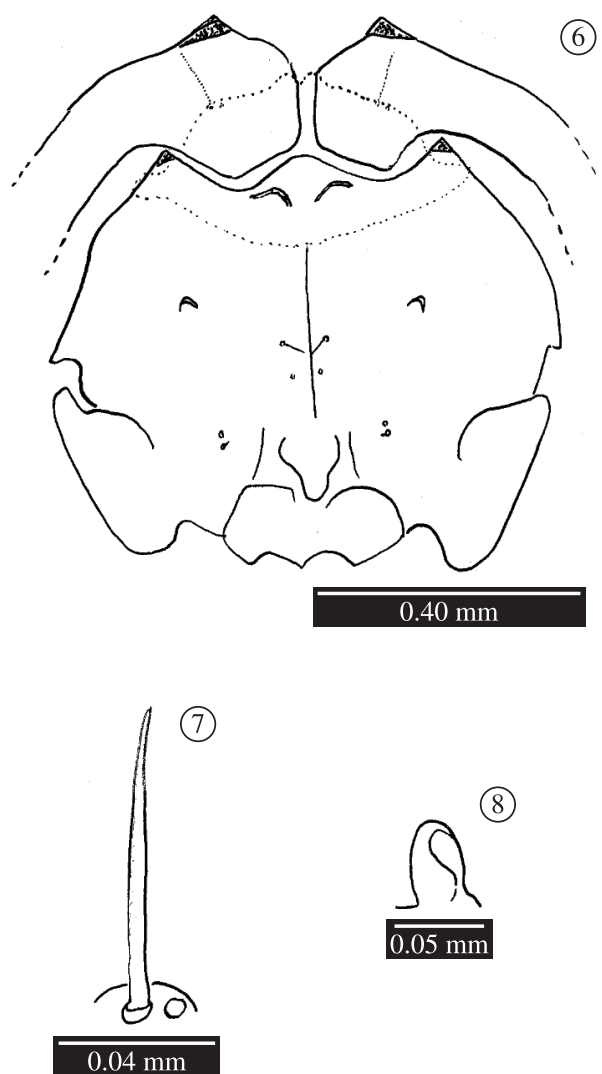

Figure 6-8. Pupa of Pisphondylia brasiliensis. 6) head, frontal view; 7) cephalic seta, dorsal view; and 8) spiracle prothoracic. the others, $0.05 \mathrm{~mm}$ long; three pairs of dorsal papillae (two pairs setose and the other without setae, and two pairs of pleural papillae setose.

Material examined. Brumadinho, Minas Gerais, Brazil, XI.2007, Graziela Fleury col.: 2 pupae, 3 pupal exuviae; Porto Alegre, Rio Grande do Sul, Brazil, 20.II.2008, same collectors: 1 pupa and 5 pupal exuviae.

\subsection{Gall description}

Pisphondylia brasiliensis induces galls on the apical and axillary buds of young shoots of the host - Guapira opposita. These galls are round or elliptic, and covered with densely disposed small leaves (Figure 11). Gall induction also alters growing patterns, resulting in a rosette of small leaves. They are commonly monothalamous, but when oviposition sites are close enough, galls may coalesce creating 1-6 larval chambers. Gall coalescence causes great differences in size final gall. Before pupating, larva feeds on plant tissues, widening the chamber and opening an escape channel up to gall epidermis. The small leaves just around the exit hole created by the larva typically senesce.

The gall covering system is formed by the epidermis of small leaves. The ground system consists of a large mass of parenchyma cells within which a great number of vascular bundles differentiate. Schlerenchyma may limit the larval chamber (Figure 12). Even though P. brasiliensis galls induced on G. opposita are essentially monothalamous -with just one larvae per chamber -, some galls collected at Brumadinho, MG, exhibited two larvae per chamber.
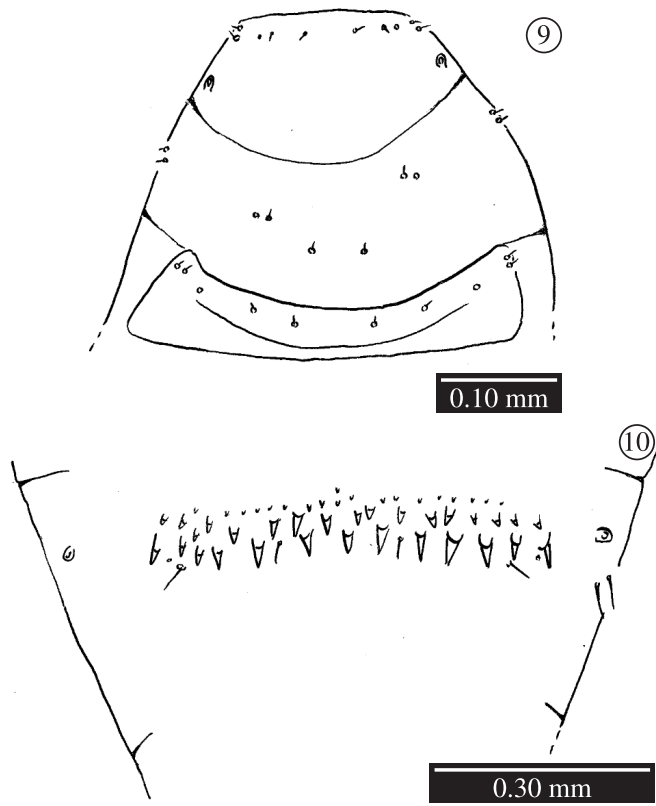

Figure 9-10. Pupa of Pisphondylia brasiliensis. 9) thoracic segments, dorsal view; and 10) abdominal segment 6, dorsal view. 

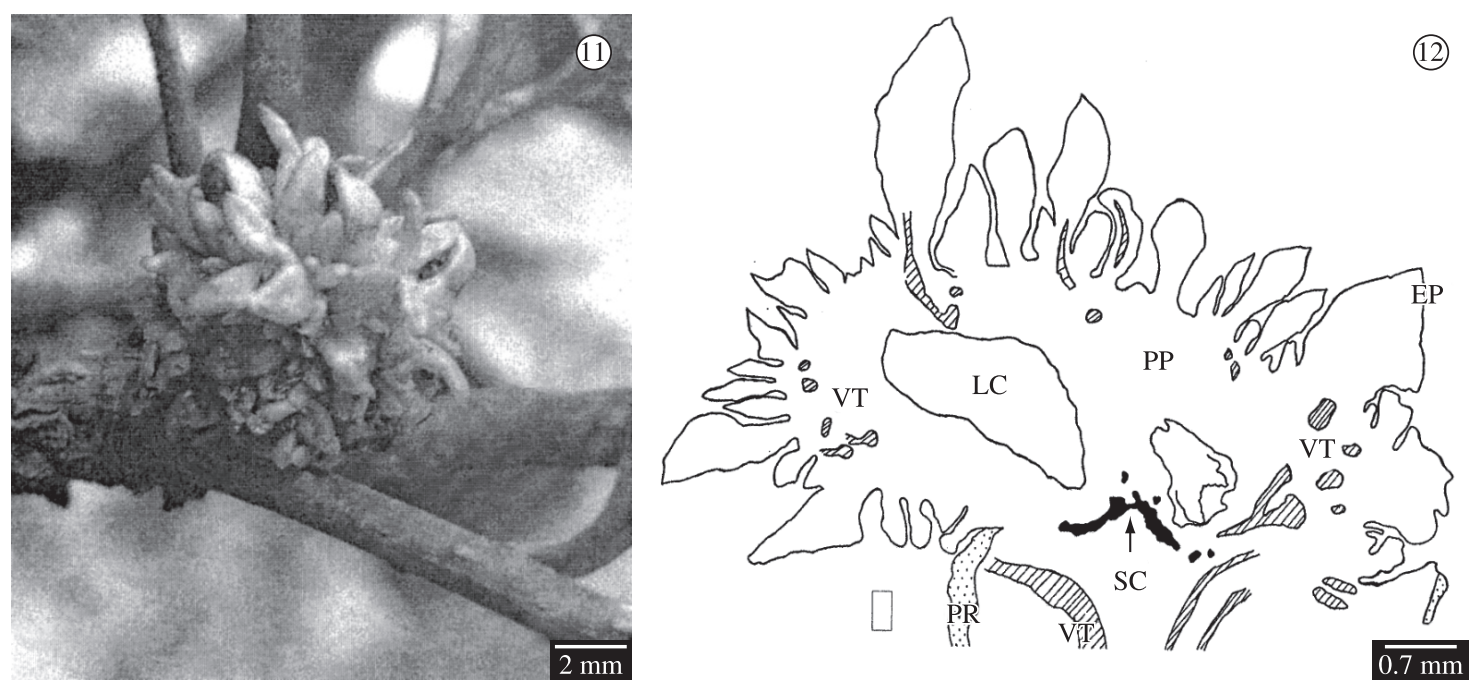

Figure 11-12. Gall of Pisphondylia brasiliensis.11) general aspect of external morphology evidencing cover of small leaves; and 12) diagram of internal structures with predominance of parenchyma cells interspersed with small vascular bundles.

\section{Discussion}

The galls of $P$. brasiliensis are very distint from those of $P$. salvadorensis. The former can be described as a rosette of small leaves, whereas the latter is a hemispherical or blister hairy gall on leaves.

The pupa of $P$. brasiliensis differs from that of P. salvadorensis by the following characteristics: 1) body length: $3.2 \mathrm{~mm}$ in P. brasiliensis; $2.6 \mathrm{~mm}$ in P. salvadorensis; 2) upper frontal horn: present in $P$. brasiliensis and absent in $P$. salvadorensis; 3 ) lower frontal horn: present in $P$. brasiliensis and absent in $P$. salvadorensis; 4) number of rows of dorsal spines on abdominal segments 2-9: two in P. brasiliensis and four in P. salvadorensis; 5) length of prothoracic spiracle: normal in $P$. salvadorensis $(0.135 \mathrm{~mm}$ long) and reduced in $P$. brasiliensis; 6) number of facial lateral papillae: two pairs in $P$. brasiliensis and three pairs in $P$. salvadorensis; 7) lower facial papillae: one pair setose and other bare in $P$. brasiliensis and both pairs setose in P. Salvadorensis, and 8) length of dorsal spines: $0.050 \mathrm{~mm}$ in P. brasiliensis and $0.064-0.065 \mathrm{~mm}$ in $P$. salvadorensis.

The female of Pisphondylia can be characterised by having: 1) flagellomeres 9-12 progressively and conspicuously shortened; 2) circumfila wavy; and 3) ovipositor protrusible, elongated, pliable, with long ventral, sparse dorsal setae and tiny cercus. The ovipositor of Pisphondylia resembles that of Bruggmannia Tavares, 1916, and wavy circumfila are also found in some species of Bruggmannia (Gagné, 1994). But in Pisphondylia, the flagellomeres 9 to 12 are progressively and conspicuously shortened, differing from those of Bruggmannia, which are subequal in length. Flagellomeres 9-12 progressively and conspicuously shortened are found in many Schizomyiina, as in Anasphondylia Tavares, 1920, Burseramyia Möhn, 1960, Metasphondylia Tavares, 1918, Pisoniamyia Möhn, 1960, Proasphondylia Felt, 1915, Schizomyia Kieffer, 1889, and Stephomyia Tavares, 1916, and in all Asphondyliina. Flagellomeres subequal in length are found only in Bruggmannia, Macroporpa Rübsaamen, 1916 and Polystepha Kieffer, 1897 among all Asphondyliini.

Galls from the two sampling areas are quite similar except for the coalescence and number of larval chambers, which may reveal differences in insect strategies for survival. For instance, Hinz (1998) found a higher probability of parasitoid attack in multi-chambered galls than in singlechambered ones. When females oviposit at the same site, their offspring might compete for vital resources, which is not essentially positive for species success. For the host plant, this oviposition behaviour may result in wider galls, and be more harmful because of a more powerful sink of photossimilates to gall site.

Acknowledgements - To CAPES, CNPq (472491/2003-2, 304851/2004-3, 084/2007-0 e 301197/2007-5) and FAPERJ (E-26/171.290/2006) for financial support; to Dr. Marcos Sobral, from BHCB Herbarium (Departamento de Botânica ICB/UFMG) for plant species identification.

\section{References}

COURI, MS. and Maia, VC., 1992. Considerações sobre Pisphondylia Möhn, 1960 (Diptera, Cecidomyiidae, Asphondyliidi), com descrição de uma espécie nova do Brasil. Revista Brasileira de Entomologia, vol. 36, no. 4, p. 729-730. 
FURLAN, A., 1996. A tribo Pisonieae Meisner (Nyctaginaceae) no Brasil. São Paulo: Instituto de Biociências, Universidade de São Paulo. [Tese de doutorado].

GAGNÉ, RJ., 1994. The gall midges of the Neotropical region. Ithaca: Cornell University Press. 352p.

HINZ, HL., 1998. Life hstory and host specificity of Rhopalomyia n. sp. (Diptera: Cecidomyiidae), a potential biological control a of scentless chamomile. Environmental Entomology, vol. 27, no. 6 , p. $1537-1547$
JOHANSEN, DA.,1940. Plant microtechnique. New York: McGraw-Hill Book. 523 p.

KRAUS, JE. and ARDUIN, M., 1997. Manual Básico de métodos em morfologia vegetal. Seropédica: EDUR. 198p.

MAIA, VC., 2005. Catálogo dos Cecidomyiidae (Diptera) do estado do Rio de Janeiro. Biota Neotropica (Ed. Portuguesa), vol. 5 , p. 1-26.

MÖHN, E., 1960. Gallmücken (Diptera, Itonididae) aus El Salvador. Senckenbergiana Biologica, vol. 41, no. 5/6, p. 333-358. 
